\title{
The Effect of $\alpha$-Amylase on Chemical and Baking Qualities of Bread Produced from Fluted Pumpkin Seed Flour (Telfoiria Occidentialis Hook) and Wheat Flour
}

\author{
Wordu, G. O. and Akusu,O.M. \\ wordugab@yahoo.com
}

\begin{abstract}
The effect of blending wheat flour (WF) with fluted pumpkin (Telfairia accidentalis Hook) seed flour at levels of $0-25 \%$ on the doush quality and chemical properties of bread were investigated using grindamyl alpha amylase enzyme as an improver. Bread loaves were baked using the straight - dough procedure and evaluated for baking quality, chemical composition and sensory properties. The results showed the loaf volume of bread decreased from $5630 \mathrm{~cm}^{3}$ to $5200 \mathrm{~cm}^{3}$ for the $0.4 \%$ level of dough improver representing $25 \%$ decrease while the $1 \%$ level of dough improver showed a decease in loaf volume from $5500 \mathrm{~cm}^{3}$ to $4500 \mathrm{~cm}^{3}$ representing $18 \%$ reduction. Results of sensory evaluation showed there were no significant differences between 5 and $10 \%$ substitution levels of the fluted pumpkin flour and the control. The values obtained showed that the flour blends can still produce acceptable bread but the $0.4 \%$ level of the alpha amplase enzyme gave a better loaf valume than the $1 \%$ level.
\end{abstract}

Keywords: A prospective study of egg consumption pattern of adults in PH/LGA of choice

\section{INTRODUCTION}

Considerable effort has been made in fortifying wheat flour with high protein plant materials especially legumes and oil seeds or protein plant concentrates to increase the protein content and improve the amino acid balance of baked bread loaves. In many developing countries, Nigeria inclusive, protein calorie malnutrition (PCM) is still common due to the exorbitant cost and inadequate supply of protein from animal sources. This brought about the need for the study of the food consumption and potential use of protein from locally available food crops especially under utilized high protein oil seeds and legume (Enujiugha et al, 2003).

Fluted pumpkin (Telfaina occidentialis Hook) seed is one of such relative neglected but potentially valuable as a high protein oil seed for use as flavouring agent or food protein supplement in many tropical countries (Longe, et al, 1983). Fluted pumpkin is native to West Africa and produce abundant quantities of seeds. Expanding the food applications for it would increase its versatility and utility. One of such application include processing into flour for use in the production of high protein bread. It has been reported that fluted pumpkin has high nutritional quality and a fairly well balanced amino acid composition, with a comparatively higher level of lysine, compared to wheat grain (Giami, 2008). In view of this, the development of value added produces using fluted pumpkin with wheat composite flour could lead to the production of novel products with improved nutritional value.

The production of bread with composite flour or incorporation of high protein additives in general requires the use of chemicals generally called surfactants as well as another class called dough improvers like leathin, ascorhic acid and fungal amylase.

Improvement in the texture and shelf life of flat breads had been reported by many authers using oxidizing agents and $\alpha$-amylase enzyme. It has been reported that addition of an emulsifier with $\alpha$ amylase improved the texture of chapatti as well as its keeping quality.

This study investigated the substitute graded levels $(0.25 \%)$ of wheat flour with fluted pumpkin flour and to examine the effect of these blends on the chemical qualities an acceptability of bread baked with the composite flour using $\alpha$-amylase.

\section{Materials AND Methods}

Mature fresh and healthy fluted pumpkin (Telfairia occidentalis Hooks) fruits were bought from a local market in Port Harcourt, capital of Rivers State, Nigeria. The seeds were carefully separated 
from the pulp and husks, and used in the experiment, commercial wheat flour (plain, golden crown brand) was obtained from Nigeria flour mills Ltd, Port Harcourt, Nigeria, $\alpha$-amylase (Roche, Germany), sugar baking fat, bakers yeast were supplied also by Nigeria flour mills Ltd, Port Harcourt. All other reagents used were of analytical grade obtained from the department of food science and technology laboratory.

Fluted pumpkin flour was prepared as indicated in the figure 3.1 below fluted pumpkin seeds intact seed coats were boiled in a covered stainless steel pot for one hour. The cooked seeds were dehulled manually and oven dried $\left(60^{\circ} \mathrm{C}, 24 \mathrm{~h}\right)$ in a hot air fan oven (model QUB 305010G, Gallenkamp, UK). Dried dehulled seeds were ground using a laboratory mill (Numex pep mill, India), screened through a $0.25 \mathrm{~mm}$ British standard sieve (model BS 410, Endicots, UK). Flour obtained were defatted by solvent extraction in a soxhlet apparatus (Tecator Inc, Colorado, U.S.A.) for eight hours using petroleum ether (B.P. $40-60^{\circ} \mathrm{C}$ ). The defatted flour were spread on aluminum trays and dried in a hot air fan oven $\left(70^{\circ}, 30 \mathrm{~min}\right)$ to expel residual petroleum ether and cooled to room temperature, then stored in polythene bags and stored in refrigerator until used.

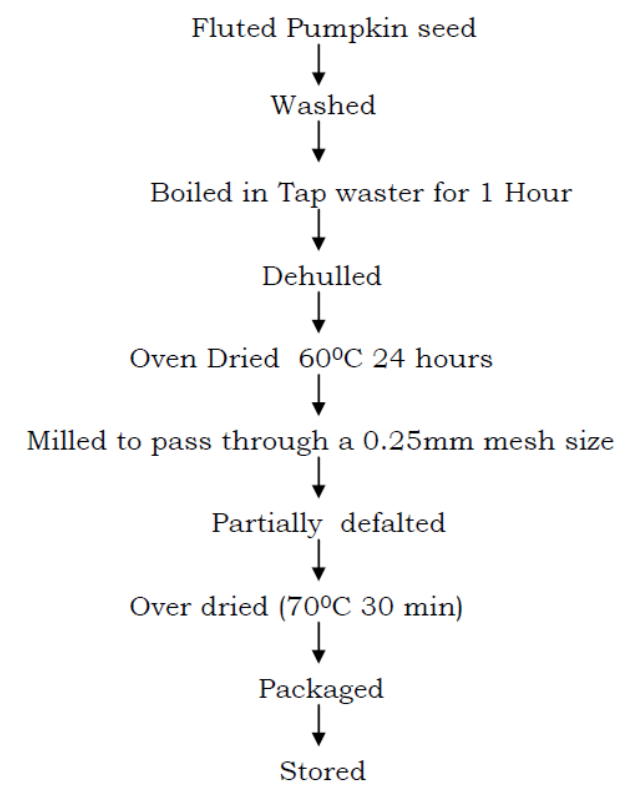

Figure3.1. Flow chart for the production of fluted pumpkin flour

The preparation of wheat flour/fluted pumpkin flour blends (FNF) were as follows; blends containing $5,10,15,20$ and $25 \%$ of FPF replacing wheat flour (WF) were prepared by gradual mixing of FPF into WF in a chopin MR $2 \mathrm{~L}$ rotary mixer. The wheat flour was mixed with graded levels $(0.4 \%$ and $1 \%$ ) of grindamyl amylase enzyme. The resultant blends were formulated into dough and used for the study.

\subsection{Bread Baking}

Baking was carried out in the quality control laboratory of the Nigeria flour mills Ltd, Port Harcourt, Nigeria. The wheat flour and wheat flour fluted pumpkin blends were baked using the straight dough method (Chauhan et. al, 1992) with slight modifications. The baking formula as 500g of flour blend, 4 grain of compressed baker's yeast, 4 grams of table salt 35 grams of sugar, 10 grams of vegetable shortening and $280 \mathrm{ml}$ approximately of water.

All the ingredients were mixed in a pan manually for about ten minutes. The dough were fermented for sixty minute at $30^{\circ} \mathrm{C}$ and baked at $210^{\circ} \mathrm{C}$ for $45 \mathrm{~min}$ Baked bread were divided into two lots. One lot was used for the measurement of bread characteristics while the second lot was used for sensory evaluation.

\subsection{Baking quality of bread}

The weight of the bread loaves were measures using the weighing scale (model mettler Toledo max 3100 , Switzerland). The individual loaves were weighed separated and the values noted. The values were done in triplicate. The height of each breadloaf was measured using two metre rules; placed at right angles to each other to mark off the values obtained for each loaf. The loaves were cut in half carefully and the middle measured in triplicate. 
The loaf volumes were obtained using the seed displacement method. The method employed used wheat in place to rapeseed. The process involved placing the bread loaf in a container after wheat kennels were poured into a graduated container filed until a mound was formed. The hand was used to cut off the excess grain seeds which were placed in a calibrated cylinder and the height reached by the seeds noted. The height was taken as the corresponding volume of the loaf. The specific volume was obtained by dividing loaf volume by its corresponding loaf weight.

\subsection{Chemical analysis of bread loaves}

The chemical analysis of the carbohydrate content of the bread samples were expressed as total carbohydrate by difference. The summation of percentage moisture, protein, fat and fiber use substrated from 100.

The fat determination was based on the total extraction of all lipids contained in the sample with petroleum ether using sxhlet micro fat extractor procedure. An extraction flask was washed and dried in the oven. It was then allowed to cool in the desicator and weighed. Soxhliet extractor was fitted with reflux condenser and water and allowed to flow through the consider. 29 of dried ground sample was placed on a fat free extraction thimble plugged lightly with cotton wool. The thimble containing weighted sample was put into the soxhlet extractor. About $300 \mathrm{ml}$ of petroleum ether was pouned into the weighed flask and the extraction apparatus was set up on the electro thermal extraction unit. All contact points were tightened before heating the flask to avoid fire and reflux sample extraction was done for 5 hours at moderate boiling. The flask was allowed to cool before the thimble as removed by distillation on a boiling water bath. The last traces of solvent were removed by heating the flask for 30 minutes at $103^{\circ} \mathrm{C}$. the flask was then transferred into a desicator to cool and then weighed. The flask and the fat were weighed and fat content calculated as follows:

$$
\% \text { Fat }=\frac{(\text { weight of flask }+ \text { fat })-\text { weight of empty flask }}{\text { sample weight }} \times 100
$$

The moisture content of the sample was determined using the (A.O.A.C, 2000) method was used. $2 \mathrm{~g}$ of dried ground sample was weighed into moisture can and kept in an all current oven at a temperature of $105^{\circ} \mathrm{C}$ for 3 hours. The loaf was cut into $3 \mathrm{~mm}$ slices and dried on paper over might in a warm room so as to remain crisp and brittle. The sample was in equilibrium so moisture content remains constant during grinding. The can was then removed cooled in a dessicator and weighted. This was repeated until a constant weight was obtained. The differences in weight represents the moisture content.

Thus, $\%$ moisture content $=\quad$ Weight of water loss $\times 100$

Weight of sample

i.e. $\%$ moisture $=100$ - Total solid (dry matter)

To determine the ash content, $3 \mathrm{~g}$ of finely ground, dry samples were put into labeled porcelain cruables. The samples were charred by adding analytical grade alcohol to each porcelain for $10 \mathrm{~min}$ and ignited using match sticks. The samples were allowed to burn and an extinguishing they (samples) were placed in a dessicator. After cooling in the dessicator they were placed in the electric muffle furnace preset at $550^{\circ} \mathrm{C}$ and allowed to ash for 3 hours. He samples were removed, cooled in a dessicator and their final weights determined.

$\%$ Ash $=\underline{\text { (weight of curable }+ \text { Ash })-(\text { Wt of empty crucide })} \times 100$

\section{Weight of sample}

The crude protein determination followed the (AOAC 2000) method. The principle involved conversion of the nitrogen component of food (except nitrate and nitrite nitrogen) into ammorium sulphate which is then converted to ammonia gas which is collected in excess boric acid. Subsequently, the nitrogen is estimated by titration of the ammonium borate with standard acid $(\mathrm{HCl})$.

29 of sample was weighed into a kyeldahl flask 59 of unhydrous sodium sulphate was added. Then, $1 \mathrm{~g}$ of copper sulphate, a speck of selenium was also added into the mixture, $75 \mathrm{ml}$ of concentrated sulphuric acid and 5 glass beads was added. In the fume cupboard, gentle heating was applied at first 
and then increased with occasional shaking till green colour results. The solution was cooled while the particles at the mouth and neck of the flask was washed down with distilled water. Heat was reapplied until green colour disappears. It was cooled. The cool digest was washed into a $250 \mathrm{ml}$ volumetric flask and mad up to the market with distilled water. The solution was distilled using markham distillation apparatus, which was prerun with steam for $15 \mathrm{mins}$ before use.

Under the condenser, a $100 \mathrm{ml}$ conical flask containing $5 \mathrm{ml}$ boric indicator was placed. $5 \mathrm{ml}$ of the digest was pipetted into the apparatus through the small funnel apartune washed down with distilled water followed by $5 \mathrm{ml}$ of $60 \% \mathrm{NaoH}$ solution. Steam through for about $7 \mathrm{mins}$ ot collect enough ammonium sulphate. Then, the receiving flask was removed and the solution was titrated using $0.01 \mathrm{~N}$ hydrochloric acid. The nitrogen content was calculated as follows:-

$\%$ Nitrogen $=$ vol. of acid to titrate blank x N Acid x $0.014 \times 100$

$$
\text { Weight of sample }
$$

Crude protein $=\%$ Nitrogen $\times 6.25$

\subsection{Sensory evaluation}

A 20 member panel comprising students from the University of Science and Technology and trained staff of Nigeria flour Mills Ltd, Port Harcourt, was used to evaluate sensory properties of bread eighteen hours (18h) after baking. Panelists attended two sessions and at each session samples (three sliced pieces of bread of uniform size and thickness) were served on white saucers identified with 3 digit code numbers to eliminate bias. Water was provided to rinse the mouth between evaluations and covered expectoration cups if they did not wish to swallow the samples. Each sample was rated, with reference to the control (100\% wheat flour) bread for crust, colour, crumb colour crumb texture, flavour and overall acceptability on a hedonic scale of 1 to 9 where $1=$ dislike extremely and $9=$ like extremely (larmond, 1977).

\section{ReSUlts}

The baking quality of bread from wheat fluted pumpkin seed flour blends using grindampt amylase enzymes is shown in Table 1. The loaf height shows a slight increase for the $1 \%$ usage level of the enzyme as against the $0.4 \%$. However, values at the $10 \%$ level of fluted pumpkin addition to the blend shows a slight increase for the $0.4 \%$ level of enzyme of $20.2 \mathrm{~cm}$ as against $20.0 \mathrm{~cm}$ for $1 \%$ level representing $1 \%$ increase. The result shows that as the percentage of the fluted pumpkin flour increased in the blend, there was a decrease in the loaf volume for both usuage levels of enzyme.

Table1. Baking qualities of wheat - Fluted pumpkin composite flour Bread using $0.4 \%$ and $1 \%$ Grindamyl amylue enzyme

\begin{tabular}{|c|c|c|c|c|c|c|c|c|}
\hline $\begin{array}{c}\text { Pumpkin flour level } \\
\text { in bread }\end{array}$ & \multicolumn{2}{|c|}{ Leaf height (cm) } & \multicolumn{2}{c|}{ Loaf volar $\left.\mathbf{( c m}^{3}\right)$} & \multicolumn{2}{l|}{ Loaf weight (g) } & \multicolumn{2}{c|}{$\begin{array}{l}\text { Specific } \\
\text { volume }\end{array}$} \\
\hline$\%$ & $0.4 \%$ & $1 \%$ & $0.4 \%$ & $1 \%$ & $0.4 \%$ & $1 \%$ & $0.4 \%$ & $1 \%$ \\
\hline 0 & 28.0 & 28.0 & 5630 & 5500 & 456 & 450 & 12.35 & 12.22 \\
\hline 5 & 28.0 & 28.0 & 5480 & 5430 & 430 & 435 & 12.74 & 12.48 \\
\hline 10 & 27.5 & 27.3 & 5350 & 5400 & 420 & 415 & 12.74 & 13.01 \\
\hline 15 & 27.0 & 26.9 & 4800 & 4900 & 408 & 410 & 11.76 & 11.95 \\
\hline 20 & 26.0 & 26.2 & 4300 & 4800 & 400 & 405 & 10.75 & 11.85 \\
\hline 25 & 20.0 & 20.2 & 4200 & 4500 & 390 & 402 & 10.74 & 11.19 \\
\hline
\end{tabular}

Mean of triplicate determinations; Means with the same superscript within the same column do not differ $(P>0.05)$.

However, $0.4 \%$ level at $5 \%$ substitution level produced bette volume and tended to decrease below the $1 \%$ level from 10 to $25 \%$ level of fluted pumpkin flour, suggesting the $1 \%$ level may be better, when incorporated into the blend compared to the $0.4 \%$ level of enzyme used; but the control $0 \%$ fluted pumpkin flour produced larger volume breads. The control also produced highest loaf weight as can be seen from the table. However, at $10 \%$ level of fluted pumpkin flour substation the $0.4 \%$ enzyme level produced a loaf weight of $420 \mathrm{~g}$ as against $41.5 \mathrm{~g}$ for $1 \%$ level but at other $(5,15-25 \%)$ levels the $1 \%$ level showed increased in the loaf volume of bread produced when compared to the $0.4 \%$ representing increase of between 0.5 and $3 \%$.

The specific volume followed the same trend for the control bread but the $5 \%$ level of substitution shows $0.4 \%$ level of enzyme producing a higher value than $1 \%$ level, but subsequent levels shows $1 \%$ level of enzyme produced high values, suggesting the $1 \%$ level could be better if adopted for baking. 
The Effect of $\alpha$-Amylase on Chemical and Baking Qualities of Bread Produced from Fluted Pumpkin Seed Flour (Telfoiria Occidentialis Hook) and Wheat Flour

Table 2 shows the chemical composition of bread baked from wheat - fluted pumpkin flour blends using $0.4 \%$ and $1 \%$ gindamyl amylase enzyme as dough improver. Crude protein values shows

Table2. Chemical Composition of bread Baked from wheat-fluted pumpkin flour blends using $0.4 \%$ and $1 \%$ grindamyl Amylase

\begin{tabular}{|c|c|c|c|c|c|c|c|c|c|c|c|c|}
\hline Treatment & \multicolumn{2}{|c|}{$\begin{array}{c}\text { Crude } \\
\text { protein }\end{array}$} & \multicolumn{2}{c|}{$\begin{array}{c}\text { Moisture } \\
\text { enzyme }\end{array}$} & \multicolumn{2}{c|}{$\begin{array}{c}\text { Crude fiber } \\
\text { levels }\end{array}$} & \multicolumn{2}{c|}{ Carbohydrate } & \multicolumn{2}{c|}{ Lipid } & \multicolumn{2}{c|}{ Ash } \\
\hline 0 & 9.25 & 8.75 & 20.00 & 23.20 & 16.60 & 13.97 & 50.20 & 50.18 & 2.25 & 2.80 & 1.10 & 1.10 \\
\hline 5 & 10.98 & 10.95 & 22.10 & 24.25 & 11.02 & 9.90 & 50.10 & 49.25 & 4.60 & 4.50 & 1.15 & 1.20 \\
\hline 10 & 11.95 & 11.80 & 22.50 & 25.10 & 9.64 & 9.10 & 49.80 & 48.00 & 4.90 & 4.80 & 1.20 & 1.21 \\
\hline 15 & 12.70 & 12.30 & 23.50 & 26.30 & 10.05 & 8.45 & 47.45 & 47.90 & 5.00 & 5.00 & 1.35 & 1.30 \\
\hline 20 & 13.80 & 13.60 & 24.50 & 28.50 & 9.06 & 7.45 & 46.30 & 43.90 & 5.18 & 5.15 & 1.40 & 1.41 \\
\hline 25 & 15.50 & 15.00 & 25.25 & 29.10 & 8.88 & 5.99 & 43.22 & 42.55 & 5.40 & 5.35 & 1.70 & 1.75 \\
\hline
\end{tabular}

Mean of triplicate determinations; mans with the same superscript within the same column do not differ $(P>0.05)$.

progressive increment as the percentage of fluted pumpkin flour increases in the blends. This was probably as a result of addition effect (Asiegbu, 1987) as fluted pumpkin has higher protein content than wheat. However, $0.4 \%$ enzyme level values were slightly more than those for $1 \%$ level.

There was also increase in the moisture level as the fluted pumpkin flour increased in the blend. This is as a result of the carry over effect since fluted pumpkin seed flour had higher moisture content than wheat grain flour $13-14 \%$. There was decrease in the values of crude fiber as the fluted pumpkin flour was increased for both the $0.4 \%$ and $1 \%$ enzyme level. This observation suggest that the $0.4 \%$ enzyme level was better in term of crude fiber content of the baked loaves but nutritionally, the $1 \%$ level may provide more useful nutrients to the body since humans cannot digest fibers in their digestive tracts.

The table shows a decrease in the total carbohydrate content of the blends as the fluted pumpkin flour increases. This implies that the fluted pumpkin, an oil seed contains less carbohydrate than wheat. On comparing the two enzymes levels, $0.4 \%$ and $1 \%$ respectively, it shows the former $(0.4 \%)$ level contain slightly higher levels of the nutrient. The lipid content of the wheat flour increased with addition of fluted pumpkin flour. This is basically true since some residual lipid may still be contained in the oil seed flour even after solvent extraction. This residual level of lipid might have raised the lipid level as a result of addition effect (Asiegbu, 1987). However, the comparison between, the two levels of enzyme usuage show very little difference in the lipid content with the $0.4 \%$ having slightly higher values.

Table 3 shows the observations made in this study with regard to the sensory properties of the loaves. There was a downward trend in the flavour from the control bread to the $25 \%$ level of fluted pumpkin substitution. This is as a result of beany flavour reported by panelists when the substitution levels exceeds $15 \%$. This may be as a result of some anti-nutritional factors like tannin and plytin present in oil seeds, thus limiting their usage. The $1 \%$ enzyme level probably gave a better flavour at the 5\% level of substitution. However, from the $10 \%$ substitution level, downwords, the $0.4 \%$ enzyme level showed higher values suggesting it may be better.

Table3. Effect of addition of fluted pumpkin to wheat flour blend on mean sensory properties of bread using $0.4 \%$ and $1 \%$ grindamyl enzyme

\begin{tabular}{|c|c|c|c|c|c|c|c|c|c|c|}
\hline Treatment & Flavour & $\begin{array}{c}\text { Crumbs } \\
\text { enzyme }\end{array}$ & \multicolumn{2}{|l|}{ Texture levels } & \multicolumn{2}{l|}{ Crumb colour } & \multicolumn{2}{c|}{ Crust colour } & \multicolumn{2}{c|}{$\begin{array}{c}\text { General } \\
\text { accept ability }\end{array}$} \\
\hline & $0.4 \%$ & $1 \%$ & $0.4 \%$ & $1 \%$ & $0.4 \%$ & $1 \%$ & $0.4 \%$ & $1 \%$ & $0.4 \%$ & $1 \%$ \\
\hline 0 & 8.8 & 8.9 & 8.8 & 8.7 & 8.8 & 8.8 & 8.8 & 9.0 & 8.6 & 9.0 \\
\hline 5 & 8.6 & 8.8 & 8.5 & 8.8 & 8.8 & 8.7 & 8.8 & 9.0 & 8.8 & 9.0 \\
\hline 10 & 8.6 & 8.3 & 8.4 & 8.5 & 8.4 & 8.5 & 8.6 & 9.0 & 8.7 & 8.3 \\
\hline 15 & 8.5 & 8.2 & 8.0 & 8.1 & 8.5 & 8.2 & 8.0 & 8.2 & 8.3 & 8.2 \\
\hline 20 & 7.9 & 7.6 & 7.8 & 7.8 & 7.7 & 8.4 & 8.1 & 8.2 & 7.7 & 7.8 \\
\hline 25 & 7.1 & 6.8 & 7.0 & 7.1 & 7.6 & 8.0 & 7.3 & 8.2 & 7.6 & 7.1 \\
\hline
\end{tabular}

Mean of triplicate determinations; where 9 = like very much, $5=$ neither like nor dislike, 1 = dislike very much; means with the same superscript within the same column do not differ $(P>0.05)$ 
In curb texture, the $1 \%$ enzyme level showed a slight preference over the control. The panelists attributed this to an improved texture. Apart from that, there was a steady downward trend up to $25 \%$ oil seed substitution level. The $0.4 \%$ and $1 \%$ enzyme levels shows alternate higher values against each other.

In terms of general acceptability, the penalists showed preference for the 5 and $10 \%$ levels over and above the control. The $1 \%$ enzymes level was scored highest by the panelists due to fine brownish colouration.

\section{DisCuSSION}

The protein content $(9.25 \%$ to $15.5 \%)$ of pumpkin flour supplemented breads were higher than the protein levels (10-13\%) in the convential white breads (Egan et al; 1981). This high level of protein is nutritionally significant since bread is easily affordable by almost everybody. All the fluted pumpkin flour supplemented breads (5-25\%) were considered to the nutritious since the consumption of about $100 \mathrm{~g}$ of each produce formulated is expected to provide more than half of the recommended daily requirement for protein (25-30g/day) as recommended by FAO/WHO (1973) for children and young adults.

There were no significant $(\mathrm{P}>0.05)$ differences between dread loaves made from wheat flour blends containing 5-15\% fluted pumpkin flour and the control bread with respect to loaf volume, loaf weight, crust colour, crumb texture, crumb colour and general acceptability. However, there were significant decreases in these bread characteristics when pumpkin flour exceeded $15 \%$ substitution level. Reduction in bread volume as a result of blending wheat flour with more than $10 \%$ protein concentrate has been reported for sun flower (Yue et al; 1991) studies by El-Soukkary (2001) showed no significant reduction in loaf volume of bread containing up to $17 \%$ pumpkin concentrate.

The low general acceptability of the bread baked from blends containing more than $15 \%$ fluted pumpkin flour was attributed by the panelists to a beamy flavour. Flavour was a prominent factor in determining acceptability at the 5-15\% level of incorporation of fluted pumpkin flour in wheat flour blends, the flavour scores of the composite breads were acceptable and comparable to the control (100\% wheat bread). When fluted pumpkin flour was increased to higher levels, flavour scores dropped sharply. However, the panelists scored the crust and crumb colour of the $15 \%$ levels of fluted pumpkin flour bread higher than the rest of the lot.

In conclusion wheat flour supplemented at 5-15\% levels with fluted pumpkin flour produced acceptable bread with increased protein. The increases protein content has great potential for the bread to be used as protein supplement for school age children. The alpha amylase enzyme brought about improvement in the bread characteristics confirming its applicability as a bromate replaces.

\section{REFERENCES}

[1] Giami, S. Y. (2003). Chemical and nutritional properties of flours and protein concentrates from raw and processed fluted pumpkin seeds. J. Dairying, Foods, Home Sci. 22:95-100.

[2] Longe, O. G. Farini, G. O. and Fetuaga, B. I. (1983). Nutritional value of the fluted pumpkin J. Agric Food chem. 31:989-992.

[3] A.O.A.C. (2000). Official methods of Analysis $14^{\text {th }}$ edition, Association of official analytical chemists, Washington, D. C.

[4] Larmond, E. (1997). Laboratory methods for sensory evaluation of foods, Canada Department of Agriculture 33-37, 57.

[5] Asiegbu, J. E. (1987). Some Biochemical evaluation of fluted pumpkin seed. J. Sci. Food Agric 40:151-175.

[6] Egan, H. Kirk, R. S. and Sawyer, R. (1981) Pearson's chemical Analysis of Foods. $8^{\text {th }}$ Ed. London Churchill Livingstone. 18-211.

[7] FAO/WHO (1973). Energy and protein requirements. Food and Agriculture organisation, nutrition meeting reports series 52, World Health Organisation Technical Report series, 522, Rome, $121-123$.

[8] Yue, P. Hettiarachcly, N. and D'Appolonia, B. L. (1991). Native and succinylated sun flower proteins used in bread making J. Food Science 56:992 -998.

[9] El-soukkary, F. A. H, (2001). Evaluation of pumpkin seed products for bread fortification plants foods Hum. Nutr. 56: 365-384.

[10] Enujiugha, V. N., and Ayodele- Oni, O. (2003). Evaluation of nutrients and some ani-nutrients in lesser known, under utilized oil seeds. Int. J. Food Sci \& Tech. 38:525 - 528. 